\title{
The Construction of University Financial Quotient Evaluation Index System and Its Level Measurement
}

\author{
Lingling $\mathrm{Wu}^{*}$ and Zengjun $\mathrm{Gu}$
}

\author{
Shandong Technology and Business University, Yantai 264005, China \\ *Corresponding author. Email: 1957133594@qq.com
}

\begin{abstract}
As a special group of college students, financial quotient is an aspect of their value. The financial quotient level of college students has gradually become a key indicator to measure the comprehensive quality and ability of students, and it has also become a reasonable measure of the financial quotient education model of major universities. One of the standards is also an important part of the overall financial and commercial level of the Chinese. Aiming at a specific group of college students, according to the principles of index system construction, based on life cycle theory and efficient market hypothesis, this paper summarizes the existing literature research on finance and business, builds a more comprehensive and systematic index system for college students' financial and commercial evaluation. Employing this index system, the paper measures the financial and commercial level of some college students in Yantai City, Shandong Province, and invites relevant experts to evaluate the measurement results to determine the rationality and feasibility of the university's financial and commercial evaluation index system.
\end{abstract}

Keywords: Financial quotient evaluation index system, Life cycle theory, Efficient market hypothesis.

\section{OVERVIEW OF THE MEASUREMENT OF COLLEGE STUDENTS' FINANCIAL QUOTIENT LEVEL}

\subsection{The Meaning of Financial Quotient}

At present, there is no clear and unified definition of the meaning of finance and commerce in my country. Some scholars have personal opinions on the meaning of finance and commerce (as shown in Table 1). At present, there is no unified cognition.
Although there is no unified definition of the connotation of financial business, scholars basically put their focus on wealth and money when proposing their understanding of the connotation of financial business. This article summarizes the definition of different financial business concepts and combines the characteristics of the college students group ultimately to define the connotation of financial business as a person's knowledge of wealth resources, their ability to manage their wealth, and their ability to use it.

Table 1. Definition of the meaning of finance and business

\begin{tabular}{|c|l|}
\hline $\begin{array}{c}\text { Robert T. } \\
\text { Kiyosaki } \\
\begin{array}{c}\text { Sharon L. Lecht } \\
(1999)\end{array}\end{array}$ & $\begin{array}{l}\text { The concept of "finance business" was first proposed. Financial quotient refers to a person's ability to } \\
\text { recognize and control wealth, and is a collection of ability to make money, manage money, and spend } \\
\text { money. }\end{array}$ \\
\hline $\begin{array}{c}\text { Robert T. } \\
\text { Kiyosaki \& } \\
\begin{array}{c}\text { Sharon L. Lecht } \\
(1999)\end{array}\end{array}$ & $\begin{array}{l}\text { Expand the definition of financial quotient, thinking that financial quotient refers to the ability of a person } \\
\text { to create wealth, manage wealth and use wealth in a market economy according to the laws of market } \\
\text { development. }\end{array}$ \\
\hline $\begin{array}{c}\text { Guo Liang } \\
\text { \& Yang Bo (2018) }\end{array}$ & $\begin{array}{l}\text { The two believe that they can show a person's financial quotient in terms of thought, knowledge and } \\
\text { ability. Extend ideas to the aspect of finance and commerce, that is, one's understanding of wealth and } \\
\text { money creation and consumption. Knowledge is a person's information reserve for economy, wealth, etc. } \\
\text { Ability refers to the ability to create wealth and consume wealth based on the laws of economy, wealth, } \\
\text { and money that you master. }\end{array}$ \\
\hline
\end{tabular}




\subsection{Research Status of College Students' Financial Quotient Level Measurement}

\subsubsection{Build a Financial and Commercial Evaluation Index System to Study Financial and Commercial Evaluation}

The most well-known is the "China Ping An People's Finance and Economics Index Report (2011)" jointly released by China Ping An and Zero Point Research and Consulting Company in 2011. In terms of scoring the level of Chinese people's financial commerce, they finally came to a number of conclusions and characteristics such as high attitudes, lack of knowledge, and lack of practical action. This is the first study of the financial commerce index by building a mathematical model. However, this financial and commercial index is generally applicable to all groups, and it is not targeted to a certain extent for the group of college students.

Of course, there are also scholars who conduct financial and commercial research on college students. Based on the characteristics of business vocational college students, Tang Ying (2016) established a financial and commercial index system from the four dimensions of attitudes toward wealth, management and wealth acquisition behavior, wealth-related knowledge, and wealth personality. The investigation and study of the financial quotient level of college students resulted in a series of other conclusions such as that the business vocational students have a more reasonable attitude towards wealth, but they have weaker wealth character. Relatively speaking, Tang Ying's (2016) research is more relevant to the college student population. The financial quotient measurement is established by establishing an indicator system, and the influencing factors of financial quotient are analyzed based on the measurement results, and then the construction of improved financial quotient index for vocational college students is concluded, but the index system established does not have general applicability to the college students.

\subsubsection{Research on Finding Ways to Improve the Level of Financial Commerce Based on Financial Quotient Measurement}

In addition to the research on financial quotient measurement of college students through the financial quotient evaluation index system, some scholars also put forward suggestions to improve the status quo of financial quotient through the study of financial quotient measurement results. Liang Xiangdong and Qiao Hongwu (2014) conducted a sample survey on the students of a university of science and technology. Based on the survey results, they concluded that the financial and economic level of college students in China is relatively low. Colleges and universities should strengthen financial and commerce education for college students and implement embedded teaching suggestions. In addition, Guo Liang and Yang Bo (2018) also conducted financial and business evaluations on college and university students of science and engineering. The concept of money and the concept of wealth improve the overall level of financial quotient of college students.

At present, the domestic research on finance and commerce of college students is mainly a quantitative study on the overall finance and commerce level of college students, and some researchers have also discussed the methods and significance of finance and commerce education in colleges and universities and put forward relevant suggestions. On the whole, at present, the domestic academic circles are still at a relatively low level of research on the construction of the financial and commercial evaluation index system. There are few financial and commercial evaluation index systems that are generally applicable to college students, and there is a lack of comprehensiveness in considering the influencing factors of the index system.

\subsection{The Necessity of Measuring College Students' Financial Quotient Level}

\subsubsection{The Measurement of the Level of Finance and Commerce is the Guiding Standard for Improving the Level of Finance and Commerce of College Students}

In the development of the new era, there is an urgent need for comprehensive talents with various professional knowledge. The representative knowledge and skills of the financial commerce are becoming more and more important in the personal knowledge system. Based on the evaluation index system, the level of various aspects of college students' financial commerce is measured, so as to clarify the current status of college students' financial commerce level, trace the source, and take corresponding measures to improve the factors that cause college students' financial commerce level to be too low. Improve the financial quotient level of college students.

\subsubsection{The Measurement of the Level of Finance and Commerce is an Indicator to Improve the Education of Finance and Commerce in Various Universities}

The concepts that value justice over profits are traditional ideas of our country and are deeply ingrained in people's hearts. That the financial and commercial education of college students in my country has been lagging for a long time is largely influenced by 
traditional ideas. The financial and commerce level of college students reflects the current status of financial and commerce education in colleges and universities to a certain extent. To carry out financial and commerce education for college students, a relevant curriculum system should be established according to the actual situation of the level of financial and commerce of college students. It can neither deviate from the reality of college students nor be too superficial. Perfecting financial and commerce education in colleges and universities should be realistic and adapt to local conditions.

\section{THE CONSTRUCTION OF THE INDEX SYSTEM FOR MEASURING THE FINANCIAL QUOTIENT LEVEL OF COLLEGE STUDENTS}

\subsection{Principles of Index System Construction}

\subsubsection{Guiding Principle}

The evaluation index is a concrete manifestation of the measurement content of the research object, and it should fully reflect the connotation and characteristics of the measurement object from the aspect it represents.

\subsubsection{Targeted Principle}

In the specific design of the evaluation index system for college students' financial quotient, we should focus on enhancing the pertinence of the measurement index, according to the characteristics of the college student group, especially in terms of consumption habits, income level, expenditure structure and risk awareness, according to different financial quotients. The level development goal is to select the evaluation index with focus and purpose.

\subsubsection{The Principle of Comprehensiveness}

In the specific selection of university students' financial and commercial evaluation indicators, we should pay attention to the principle of comprehensiveness, and consider the possible impact of different regions, family background, age, and professional factors on the level of financial commerce from different aspects, so that the evaluation index system has an overall evaluation on the financial and commercial level of college students.

\subsubsection{Feasibility Principle}

When constructing the evaluation index system for college students' financial quotient, it is necessary to choose the measurement index that can directly obtain data as much as possible to avoid selecting the evaluation index that is difficult to be effectively quantified or difficult to count.

\subsubsection{Scientific Principles}

When using the index system to measure the level of college students' financial quotient, the selection method, selected indicators, evaluation content, etc. need to follow the objective reality, which can reflect the actual situation of the college student's financial quotient level.

\subsection{Theoretical Basis for Selecting Measurement Indicators}

\subsubsection{Life Cycle Theory}

Life-cycle theory provides a completely new interpretation of consumers' consumption behavior. The theory points out that individual consumption and savings behavior requires long-term planning to achieve the best allocation of personal consumption throughout its life cycle. According to the life cycle, people's life can be divided into different stages, and each stage corresponds to different financial goals in life. The university stage is the period when college students accumulate personal capital. College students are in the stage of preparing for a future life. The easiest and most effective way is to receive education. Therefore, when constructing the index system for measuring the level of financial quotient, we must fully consider college students' consumption expenditure structure, investment and financial management capabilities, and financial planning.

\subsubsection{Efficient Market Hypothesis}

The effective market hypothesis includes three aspects: first, everyone in the market is a rational economic man; second, the price of the stock reflects the balance of supply and demand of these rational people; third, the price of the stock can fully reflect all available information of the asset, which is "information is valid". The theoretical significance of the efficient market hypothesis lies in the fact that in the process of forming the stock price, there are certain problems in the information disclosure, information transmission, information interpretation, and information feedback. Solving these problems is the fundamental reason for improving the effectiveness of the stock market. Among them, the establishment of a mandatory information disclosure system for listed companies is the most critical issue.

College students' cognitive ability of wealth is an aspect of measuring their financial quotients. College students must have a basic understanding of capital market information when planning or investing in 
financial management, combining information disclosure in the capital market with their own risk tolerance and market change resilience and other aspects, and choose the appropriate financial management method. Therefore, when constructing the index system for measuring the level of finance and commerce, it is necessary to consider the degree of college students' understanding of the information on the market and their own risk tolerance.

This article is based on life cycle theory and efficient market theory, plus research and study of existing literature, and adjustment and modification of the traditional financial evaluation index system to make it more suitable for college students. Finally, from the three dimensions of wealth cognition ability, wealth creation ability and wealth management ability, a financial quotient evaluation index system for college students was established (as shown in Table 2).

\subsection{Build a Financial and Economic Level Measurement Index System}

The evaluation index system of college students' financial quotient includes three first-level indicators of wealth cognition ability, wealth management ability and wealth creation ability and corresponding second-level indicators under each first-level indicator.

\subsubsection{Wealth Cognitive Ability}

It mainly includes three secondary indicators: understanding of the concept of wealth, attention to financial information, and understanding of financial tools. Wealth awareness is a basic manifestation of the level of human and financial commerce. Basic grasp of wealth concepts, financial information and financial tools will help to understand wealth more deeply, and have a basic understanding of capital market information to create and manage wealth. Laying the foundation is also the key to improving the level of finance and commerce.

\subsubsection{Wealth Creation Ability}

Wealth creation ability includes risk tolerance, investment and financial management capabilities and market adaptability. A person's risk tolerance determines the strategy of investment and financial management. Based on different risk tolerances, investment and financial management are carried out in investment markets with different risk levels. The ultimate return on investment obtained is a demonstration of a person's investment capacity, which also contains one key point, the ability to adapt to changes in the market. Changes in the market may bring certain risks. Timely perception of market changes and countermeasures can offset them. This is a reflection of a person's market sensitivity and market adaptability. To a certain extent it also affects the final result of investment and financial management.

\subsubsection{Wealth Management Capabilities}

Wealth management capabilities includes the three secondary indicators of financial planning, consumption expenditure, and insurance awareness. Contemporary college students are at the stage of entering the society, and should have certain financial planning awareness and ability. At the same time, the consumption habits and expenditure structure of college students also reflect the financial quotient level of college students to a certain extent. The amount of surplus funds of college students and the management of surplus funds are important manifestations of wealth management capabilities. Therefore, the evaluation index system of college students' financial quotient in Table 2 is more applicable to the college students.

Table 2. Evaluation index system of college students' financial quotient

\begin{tabular}{|c|c|c|}
\hline $\begin{array}{l}\text { General } \\
\text { indicators }\end{array}$ & First-level indicators & Second-level indicators \\
\hline \multirow{9}{*}{$\begin{array}{l}\text { Measurement } \\
\text { Index of } \\
\text { Finance and } \\
\text { Commerce } \\
\text { Level }\end{array}$} & \multirow{3}{*}{$\begin{array}{l}\text { Wealth cognitive ability } \\
\text { (X1) }\end{array}$} & Cognition of the concept of wealth (x1) \\
\hline & & Concern about financial information (x2) \\
\hline & & Understanding of financial management tools (x3) \\
\hline & \multirow{3}{*}{$\begin{array}{l}\text { Wealth creation ability } \\
\text { (X2) }\end{array}$} & Risk tolerance $(\mathrm{x} 4)$ \\
\hline & & $\begin{array}{l}\text { Investment and financial management capabilities } \\
\qquad(\mathrm{x} 5)\end{array}$ \\
\hline & & Market resilience (x6) \\
\hline & \multirow{3}{*}{$\begin{array}{l}\text { Wealth management } \\
\text { capabilities (X3) }\end{array}$} & Financial planning $(\mathrm{x} 7)$ \\
\hline & & Consumer expenditure (x8) \\
\hline & & Remaining funds (x9) \\
\hline
\end{tabular}




\section{MEASUREMENT OF THE FINANCIAL AND COMMERCIAL LEVEL OF COLLEGE STUDENTS}

Using the constructed evaluation index system of college students' financial quotient, 600 college students from three colleges and universities of Shandong Institute of Business, Yantai University and Ludong University in Yantai City, Shandong Province were surveyed. The number of students was in freshmen, sophomores, juniors and seniors. The distribution among the four grades is relatively even, with $36.32 \%$ of the college students interviewed and $63.68 \%$ of the girls interviewed. The majors involved include liberal arts, science, engineering and economics. A survey questionnaire was used to measure the financial quotient level of college students, and the final results were analyzed and evaluated. A total of 600 copies of the "Questionnaire for Financial and Economic Level of College Students" were distributed online, with 576 valid questionnaires and a recovery rate of $96 \%$.

\subsection{Assignment of Weights to Evaluation Indexes of Financial and Economic Quotients of College Students}

Adopt the coefficient of variation method in objective weighting to obtain the weights. Based on the index system in Table 2, a corresponding questionnaire for financial quotient level of college students is designed, and the possible influencing factors of financial quotient level such as gender, major, grade, native place, parents education, family income, etc. are included in the basic information, and the second-level indicators of the index system are operationalized. Some topics are set up as a series of related questions to test the financial and commercial situation of the interviewee, and score based on the respondents' answers. Four options are designed for each question, from 1 to 4 . The higher the score, the higher the score of the survey subject on the question, and then the weight of each secondary index is calculated according to the coefficient of variation method, as shown in Table 3 .

\subsection{Measurement Results and Evaluation of College Students' Financial Quotient Level}

From Table 4, the scores of the first-level indicators are:

$\mathrm{X} 1=65.27 * 32.46 \%+53.25 * 31.88 \%+63.80 * 35.66 \%=$ 56.23

49.28

$\mathrm{X} 3=51.69 * 38.22 \%+73.22 * 30.09 \%+53.35 * 31.69 \%=$ 51.59

Total financial business score $=60.91 * 32.95 \%+49.28 * 32.38 \%+58.69 * 34.67 \%=5$ 6.37

From the above results, it can be seen that the financial quotients of college students in the three selected universities in Yantai are at a relatively low level (56.37), only the knowledge of the concept of wealth (65.27), the understanding of financial tools (63.80) and the structure of consumer expenditure have higher score. The rationality (73.22) scored higher in the three secondary indicators and the other indicators all scored lower, at a general level, which also reflects the current state of college students' low level of financial commerce. Relevant experts analyze and evaluate the survey results, and believe that the survey results are more objective and more realistic. This index system fits the actual situation of the college student group and is feasible and applicable to a certain extent.

Table 3. Index system weights

\begin{tabular}{|c|c|c|}
\hline $\begin{array}{l}\text { General } \\
\text { indicators }\end{array}$ & First-level indicators & Second-level indicators \\
\hline \multirow{9}{*}{$\begin{array}{l}\text { Measurement } \\
\text { Index of } \\
\text { Finance and } \\
\text { Commerce } \\
\text { Level }\end{array}$} & \multirow{3}{*}{$\begin{array}{l}\text { Wealth cognitive ability } \\
(32.95 \%)\end{array}$} & Cognition of the concept of wealth (32.46\%) \\
\hline & & Concern about financial information $(31.88 \%)$ \\
\hline & & Understanding of financial management tools $(35.66 \%)$ \\
\hline & \multirow{3}{*}{$\begin{array}{l}\text { Wealth creation ability } \\
\qquad(32.38 \%)\end{array}$} & Risk tolerance $(33.27 \%)$ \\
\hline & & Investment and financial management capacity (32.64\%) \\
\hline & & Market resilience $(34.09 \%)$ \\
\hline & \multirow{3}{*}{$\begin{array}{l}\text { Wealth management } \\
\text { capabilities }(34.67 \%)\end{array}$} & Financial planning $(31.69 \%)$ \\
\hline & & Consumer spending $(30.09 \%)$ \\
\hline & & Remaining funds $(38.22 \%)$ \\
\hline
\end{tabular}


Table 4. Secondary index score table

\begin{tabular}{|c|c|c|c|}
\hline $\begin{array}{l}\text { General } \\
\text { indicators }\end{array}$ & First-level indicators & Second-level indicators & Score \\
\hline \multirow{8}{*}{$\begin{array}{l}\text { Measurement } \\
\text { Index of } \\
\text { Finance and } \\
\text { Commerce } \\
\text { Level }\end{array}$} & \multirow[t]{2}{*}{$\begin{array}{l}\text { Wealth cognitive } \\
\text { ability }(32.95 \%)\end{array}$} & Cognition of the concept of wealth (32.46\%) & $\frac{65.27}{5325}$ \\
\hline & & Understanding of financial management tools $(35.66 \%)$ & 63.80 \\
\hline & \multirow{3}{*}{$\begin{array}{c}\text { Wealth creation } \\
\text { ability }(32.38 \%)\end{array}$} & Risk tolerance $(33.27 \%)$ & 43.65 \\
\hline & & Investment and financial management capacity $(32.64 \%)$ & 56.79 \\
\hline & & Market resilience $(34.09 \%)$ & 47.57 \\
\hline & \multirow{3}{*}{$\begin{array}{l}\text { Wealth management } \\
\text { capabilities }(34.67 \%)\end{array}$} & Daily financial planning (38.22\%) & 51.69 \\
\hline & & Consumer expenditure structure $(30.09 \%)$ & 73.22 \\
\hline & & Management of remaining funds $(31.69 \%)$ & 53.35 \\
\hline
\end{tabular}

\section{CONCLUSION}

This article is to comprehensively and systematically understand the current situation of college students' financial and commercial level. The traditional financial and commercial evaluation index system, the characteristics of college students and other related influencing factors are combined to build a financial and commercial evaluation index system more suitable for college students. And use this index system to measure the financial quotient level of college students in three colleges and universities in Yantai, evaluate the application results, and determine that the financial quotient measurement index system has certain applicability and feasibility for the college student population. How to use the index system of college students' financial commerce level measurement to achieve the goal of improving college students' financial commerce level or improving college financial commerce education is the content to be discussed in the follow-up, and more in-depth discussion and research are needed.

\section{ACKNOWLEDGMENTS}

Fund Project: 1. Shandong University of Commerce and Industry's 2019 Graduate Wealth Management Special Project "Study on the Measurement and Improvement Path of College Students' Financial and Commercial Level" (No.: 2019CF008) 2. Shandong University of Commerce and Industry's 2019 Wealth Management Special Construction Project "Commercial Bank Wealth Management Business Transformation
Research on Institutional Incentives, Realization Path and Effect Evaluation" (No.: 2019ZBKY058).

\section{REFERENCES}

[1] China Ping An Financial Assets Index Report [J]. Public Financial Advisors, 2011(09): 16-17.

[2] Tang Ying. 2016. Research on the construction of financial quotient index of students in western commercial vocational colleges $[\mathrm{J}]$. Journal of Xichang College (Natural Science Edition), 30(01): 65-69.

[3] Guo Liang \&Yang Bo. 2018. Survey and reflection on the current status of financial and commercial education of science and engineering college students [J]. Education Teaching Forum,(05): 48-49.

[4] Zhu Kun. 2017. Research on the strategy of cultivating financial quotient of post-95 college students [J]. Journal of Hubei University of Science and Technology, 37(04): 153-156.

[5] Wang Linzhao\&Zhang Jiaqi \& Huang Qin. 2015. Investigation and research on financial and commercial behavior of contemporary college students $[\mathrm{J}]$. Journal of Shanxi Youth Vocational College, 28(03): 33-35.

[6] Deng Renfen. 2015. Exploring the path of college students'financial and commerce education in the new period [J]. Education and Vocational, (19): 115-117. 